\title{
Recovery of Iron and Aluminum from Bauxite Residue by Carbothermic Reduction and Slag Leaching
}

\author{
K. E. Ekstroem ${ }^{1}$ (I) $\cdot$ A. Voll Bugten ${ }^{1} \cdot$ C. van der Eijk ${ }^{2} \cdot$ A. Lazou $^{1} \cdot$ E. Balomenos $^{3} \cdot$ G. Tranell $^{1}$
}

Received: 30 September 2020 / Accepted: 2 August 2021 / Published online: 20 August 2021

(c) The Author(s) 2021

\begin{abstract}
The recovery of major components of bauxite residue by carbothermic reduction at $1550-1750{ }^{\circ} \mathrm{C}$ and subsequent slag leaching in a $\mathrm{Na}_{3} \mathrm{CO}_{3(\mathrm{aq})}$ solution is studied. Iron recovers primarily to pig-iron and lime is added to tune the calcium aluminate slags towards the highly leachable mayenite phase. The concentration of aluminum in the leachate correlates well with the occurrence of mayenite and aluminum recoveries up to 50-60\% are observed. However, slags with low $\mathrm{CaO}$ additions are vulnerable to gehlenite formation and display reduced leachabilities. Formation of an inhibiting layer of $\mathrm{CaCO}_{3(\mathrm{~s})}$ on the reaction surface of calcium-aluminate particles during leaching and immobilization of aluminum in $\mathrm{CaTiO}_{3(\mathrm{~s})}$ are also suggested to play important roles in limiting the aluminum leachability. Costs related to post-processing may be reduced by achieving disintegrating slags, a behavior which is observed for slags holding high $\gamma$ - to $\beta-\mathrm{Ca}_{2} \mathrm{SiO}_{4}$ ratios. The disintegration is caused by the large volume expansion associated with the $\beta$-to- $\gamma$ transformation and as such, various factors that are known to stabilize the $\beta$-polymorph are discussed.
\end{abstract}

\section{Graphical Abstract}

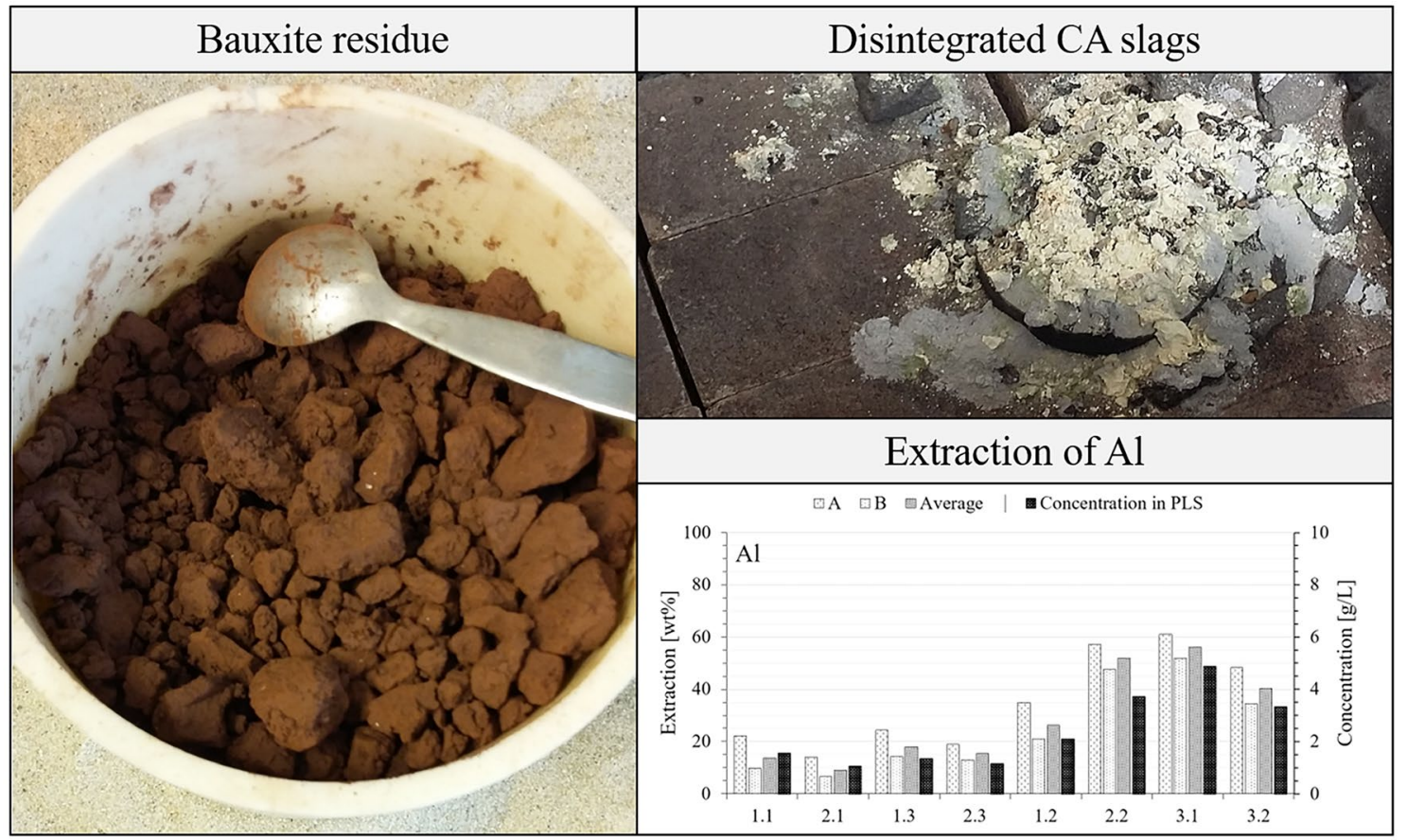

The contributing editor for this article was Yongxiang Yang.

Extended author information available on the last page of the article 
Keywords Bauxite residue $\cdot$ Recycling $\cdot$ Calcium aluminate $\cdot$ Leaching

\section{Introduction}

With the increasing demand for aluminum ( $\mathrm{Al})$, current estimates suggest that the annual generation of bauxite residue is in excess of 150 million metric tons worldwide [1]. Prior to 1980, most of the inventory was stored in lagoontype impoundments but, as available land became scarce, many plants have adopted dry-stacking methods instead. The residue is strongly alkaline and contains calcium- and sodium-aluminosilicates together with iron-, titanium- and other undissolved minerals from the Bayer process. It also typically contains $13-25 \%$ of residual alumina $\left(\mathrm{Al}_{2} \mathrm{O}_{3}\right)$, depending on the grade of the initial bauxite ore and the efficiency of alumina extraction [2]. The large quantities of stockpiled residue constitute considerable losses in what is otherwise exploitable raw material resources and are inherently accompanied by substantial environmental challenges [3]. Adapting to circular principles will therefore be essential to ensure access to future materials. Stricter regulations like the European Mining Directive [4] and the European Waste Legislation [5] put increasing constraints on landfills, and forces the industry to find alternative and more sustainable solutions for their waste streams. Despite the development of numerous processes for recovery of components, industrial utilization of bauxite residue remains below 2.5\% [1]

The Pedersen process was developed as an alternate route of refining $\mathrm{Al}_{2} \mathrm{O}_{3}$ and was employed at the $\mathrm{H} \varnothing$ yanger plant in Norway between 1928 and 1968 [6]. The process could, however, not compete with refinement of high-quality ores by the Bayer process and did not gain widespread adaptation. But as high-quality deposits are being depleted and problems related to storage of bauxite residue have escalated over the years, renewed interest has been given to the technology [7, 8]. The process was primarily developed with low-quality bauxite and other laterite ores in mind, with higher contents of iron- and silicon bearing oxides that is traditionally seen as uneconomical for the Bayer process. Extraction of iron and aluminum by carbothermic smelting and subsequent slag leaching in a sodium carbonate solution $\left(\mathrm{Na}_{2} \mathrm{CO}_{3}\right)$ leaves a residue that consists primarily of calcium-carbonate and -silicates, which may be recycled by the agriculture and/ or construction sectors. Similar concepts can also be adapted to treatment of already stockpiled bauxite residue [2]. Works by Azof et al. $[9,10]$ on synthetic binary calcium aluminate slags found that mayenite $\left(\mathrm{C} 12 \mathrm{~A} ; \mathrm{Ca}_{12} \mathrm{Al}_{14} \mathrm{O}_{33(\mathrm{~s})}\right)$ displays exceptional leaching properties, while tricalcium aluminate $\left(\mathrm{C} 3 \mathrm{~A} ; \mathrm{Ca}_{3} \mathrm{Al}_{2} \mathrm{O}_{6(\mathrm{~s})}\right)$ and monocalcium aluminate $(\mathrm{CA}$; $\left.\mathrm{CaAl}_{2} \mathrm{O}_{4(\mathrm{~s})}\right)$ display more moderate leaching properties. The high leachability of the $\mathrm{C} 12 \mathrm{~A}$ phase is primarily attributed to its clathrate structure, where oxygen anions located in the center of the cage allow for easy depolymerization. The phase has been well known in concrete research for a long time and is recognized for being thermodynamically unstable without access to secondary stabilizing template anions. It reacts readily with water and is known to retain enough hydroxyl ions to stabilize the phase up to high temperatures $[11,12]$. On the other hand, it is known to decompose under dry and/or reducing conditions if no other stabilizing compounds are present [13]. Mechanisms and stability are still heavily debated, but recent works suggests that carbon may play an important role in stabilizing the $\mathrm{C} 12 \mathrm{~A} 7$ in reducing conditions $[14,15]$. On the other hand, monocalcium dialuminate $\left(\mathrm{CA} 2 ; \mathrm{CaAl}_{4} \mathrm{O}_{4(\mathrm{~s})}\right)$ appear to be insoluble in a $\mathrm{Na}_{2} \mathrm{CO}_{3}$ solution. It was argued that the leaching is surface driven, and the reduced leachability was related to the buildup of an insoluble layer of calcite on the calcium aluminates that effectively inhibits the dissolution of $\mathrm{Al}_{2} \mathrm{O}_{3}$ [16]. Moreover, a less leachable calcium aluminate phase may also affect the leachability of others. $\mathrm{Al}$ can also be immobilized in gehlenite $\left(\mathrm{C} 2 \mathrm{AS} ; \mathrm{Ca}_{2} \mathrm{Al}_{2} \mathrm{SiO}_{7}\right)$ and the content of silica in the bauxite residue poses a great challenge for $\mathrm{Al}$ recovery [17]. The addition of $\mathrm{CaO}$ can be used for capture of $\mathrm{SiO}_{2}$ in a calcium silicate $\left(\mathrm{C} 2 \mathrm{~S} ; \mathrm{Ca}_{2} \mathrm{SiO}_{4}\right)$ phase and may have a positive effect on the $\mathrm{Al}$ recovery $[18,19]$. The hightemperature hexagonal $\alpha$-polymorph of $\mathrm{C} 2 \mathrm{~S}$ is known to go through several transformations upon cooling [20], and the monoclinic $\beta$-C2S to the orthorhombic $\gamma$-C2S transformation is associated with an especially large volume expansion of $12 \%$ that is manifested as a disintegrating slag [21]. This work seeks to valorize bauxite residue farmed from Mytilineos, Aluminum of Greece, though carbothermic production of pig-iron and leachable calcium aluminate slags. Various amounts of $\mathrm{CaO}$ are added to the smelting experiments to investigate final slag mineralogy and properties for subsequent leaching tests. Slow cooling practices are employed to ensure slag phases with high aluminum leachability and to facilitate the transformation of calcium silicate via the $\beta-\mathrm{C} 2 \mathrm{~S}$ phase. The goal is to produce a self-disintegrating slag that reduces the need for crushing the slag before leaching.

\section{Materials and Methods}

\section{Thermochemical Calculations}

Thermodynamic calculations were carried out using FactSage 7.3 thermochemical software to design experiments and predict slag compositions at equilibrium [22]. The calculations were based on a simplified bauxite residue composition, marked with ${ }^{\mathrm{a}}$ in Table 1 . Carbon and $\mathrm{CaO}$ was 
Table 1 The chemical composition of the bauxite residue, charcoal and lime used in the current experiments, as measured by XRF

\begin{tabular}{llll}
\hline Species $(w t \%)$ & Bauxite residue & Charcoal & Lime \\
\hline $\mathrm{Fix}-\mathrm{C}$ & - & 89.06 & - \\
$\mathrm{Na}{ }_{2} \mathrm{O}$ & $3.44^{\mathrm{a}}$ & - & 0.12 \\
$\mathrm{MgO}$ & 0.14 & 0.22 & 0.65 \\
$\mathrm{Al}_{2} \mathrm{O}_{3}$ & $22.81^{\mathrm{a}}$ & 2.83 & 0.24 \\
$\mathrm{SiO}_{2}$ & $7.81^{\mathrm{a}}$ & 5.69 & 0.47 \\
$\mathrm{~K}_{2} \mathrm{O}$ & & 0.18 & 0.04 \\
$\mathrm{P}_{2} \mathrm{O}_{5}$ & 0.05 & - & 0.02 \\
$\mathrm{SO}_{3}$ & 0.60 & - & 0.08 \\
$\mathrm{CaO}$ & $9.91^{\mathrm{a}}$ & 0.43 & 96.56 \\
$\mathrm{CaCO}_{3}$ & - & - & 1.72 \\
$\mathrm{TiO}_{2}$ & $5.91^{\mathrm{a}}$ & - & 0.02 \\
$\mathrm{Ti}$ & - & 0.10 & - \\
$\mathrm{Cr}_{2} \mathrm{O}_{3}$ & 0.28 & & - \\
$\mathrm{Fe}_{2} \mathrm{O}_{3}$ & $44.95^{\mathrm{a}}$ & 0.87 & 0.08 \\
$\mathrm{Fe}$ & - & 0.61 & - \\
$\mathrm{NiO}$ & 0.14 & - & - \\
$\mathrm{ZrO}_{2}$ & 0.19 & - & - \\
\hline
\end{tabular}

${ }^{\mathrm{a} C}$ Components used in the thermochemical calculations

added to the calculations as pure components and the system temperature was set to respective smelting temperatures of the samples. Descriptions of oxide solutions, including liquid slag (SLAG) and monoxide $(\mathrm{MeO})$ were taken from the FactSage FToxide database. The FSstel database was used to calculate the liquid metal (Liqu) solution, and thermodynamic properties of pure substances and gas species were taken from the FactPS database. Due to the lack of the pure mayenite specie in the databases, a custom database was created with thermodynamic data from Hallstedt [23].

\section{Pre-treatment and Smelting}

The bauxite residue held approximately $25 \mathrm{wt} \%$ moisture and dried at $130{ }^{\circ} \mathrm{C}$ for $12 \mathrm{~h}$ prior to smelting in an alumina crucible (Fig. 1a). Charcoal was dried under similar conditions and sized to a fraction of $4.75-16 \mathrm{~mm}$. The chemical composition of the dried residue is summarized along with the remaining raw materials in Table 1. Prior to smelting, $1000 \mathrm{~g}$ of dried bauxite residue was mixed with $200 \mathrm{~g}$ charcoal and $150-350 \mathrm{~g}$ of $\mathrm{CaO}$ in graphite crucibles. The crucibles were placed in a $75 \mathrm{~kW}$ induction furnace (Fig. 1b), heated to temperatures of $1550-1750{ }^{\circ} \mathrm{C}$ and held for $90 \mathrm{~min}$. An overview of the different samples, $\mathrm{CaO}$-additions and smelting temperatures are shown in Table 2. Cooling proceeded by $10^{\circ} \mathrm{C} / \mathrm{min}$ down to $1330{ }^{\circ} \mathrm{C}$, and the furnace was held at this temperature for another $30 \mathrm{~min}$ before it was shut down. The samples were left inside the furnace to be cooled down to room temperature overnight. Disintegrated slags were separated from the metal and sieved to below $125 \mu \mathrm{m}$ with little effort. Solid slags were manually separated from the metal by hand, crushed and sieved to below $125 \mu \mathrm{m}$. Samples were also cut from the metals and cast into epoxy for elemental characterization.

\section{Leaching}

Parameters similar to those used in a previous study by Azof et al. were used [10]. Approximately $2.5 \pm 0.01 \mathrm{~g}$ of slag was prepared for each experiment. A solution of $102.6 \mathrm{~g} / \mathrm{l}$ $\mathrm{Na}_{2} \mathrm{CO}_{3(\mathrm{~s})}$ was heated to a temperature of $45^{\circ} \mathrm{C}$. The leaching was performed with a $20 \mathrm{ml} / \mathrm{g}$ liquid-to-solid ratio in an open beaker, heated by a hot plate under a magnetic stirring speed of $300 \mathrm{rpm}$, at residence time of $60 \mathrm{~min}$. The final leachate and residue were filtered through an ashless grade filter paper, and the pregnant liquid solution (PLS) was stored in a vial while the residue was dried at $100{ }^{\circ} \mathrm{C}$ overnight.

\section{Characterization}

Phase and compositional analysis of the bauxite residue and the produced slags were done by a Bruker D8 A25 DaVinci $\mathrm{X}$-ray Diffractometer (XRD) with $\mathrm{Cu}-\mathrm{K} \alpha$ radiation and a Philips PW 2404 X-ray Fluorescence spectrometer (XRF). Identification of obtained XRD peaks and a semi-quantitative analysis of slags before and after leaching was done in the DIFFRAC.EVA v.5.1 software. Despite the inherent limitations in the semi-quantitative analysis method it is primarily used to get an impression of the distribution of $\mathrm{Al}$ and silicon $(\mathrm{Si})$ in the slags before and after leaching. Microscopic analysis of particles and phases were carried out by a JEOL JXA-8500F Electron Probe Microanalyzer (EPMA) and a Zeiss Ultra 55 FE-SEM. The elemental composition of the pig-iron samples was measured by the same EPMA instrument, where the reported values are averaged over three individual measurement points on each sample. A Thermo Scientific Element 2 high-resolution Inductively Coupled Plasma Mass Spectrometer (ICP-MS) instrument was also used to analyze extracted elements in the pregnant solution (PLS) after leaching.

\section{Results}

\section{Characteristics of the Bauxite Residue}

In addition to the chemical composition previously given in Table 1, mineralogical phase analysis done by XRD is presented in in Fig. 1c. The peaks of the XRD diffractogram have been identified to being related primarily to boehmite, diaspore, gibbsite, calcite, katoite, anatase, sodium aluminum silicate, hematite and cancrinite. 

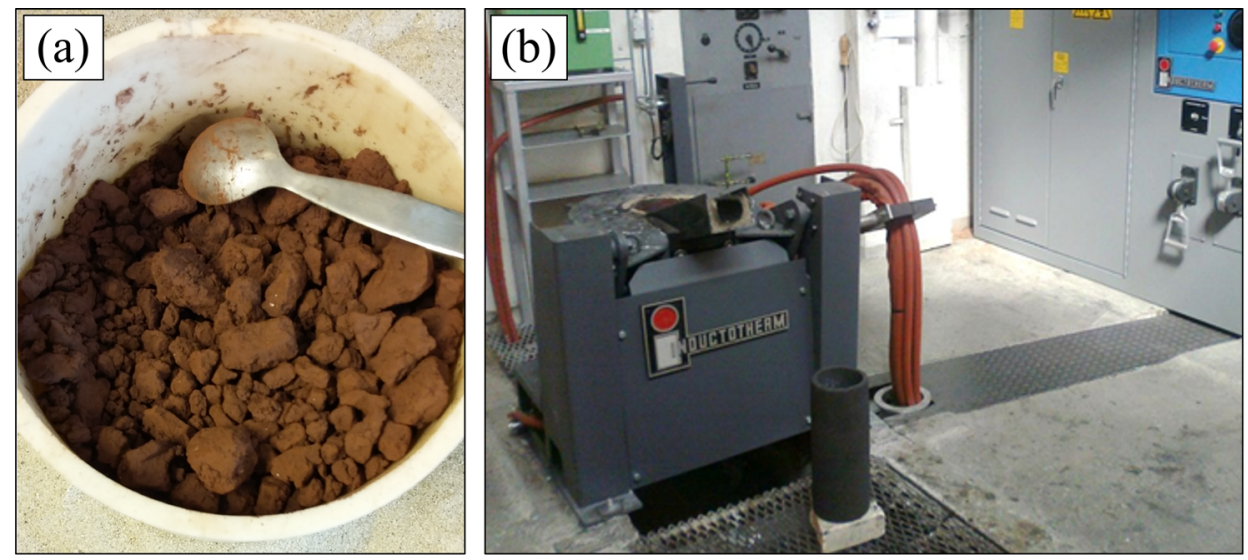

(c)
$\circ$ Boehmite
$\nabla$ Diaspore
$\diamond$ Gibbsite
- Katoite
$\square$ Calcite
$\triangle$ Hematite
Cancrinite
- Sodium Aluminum Silicate
$\rightarrow$ Anatase

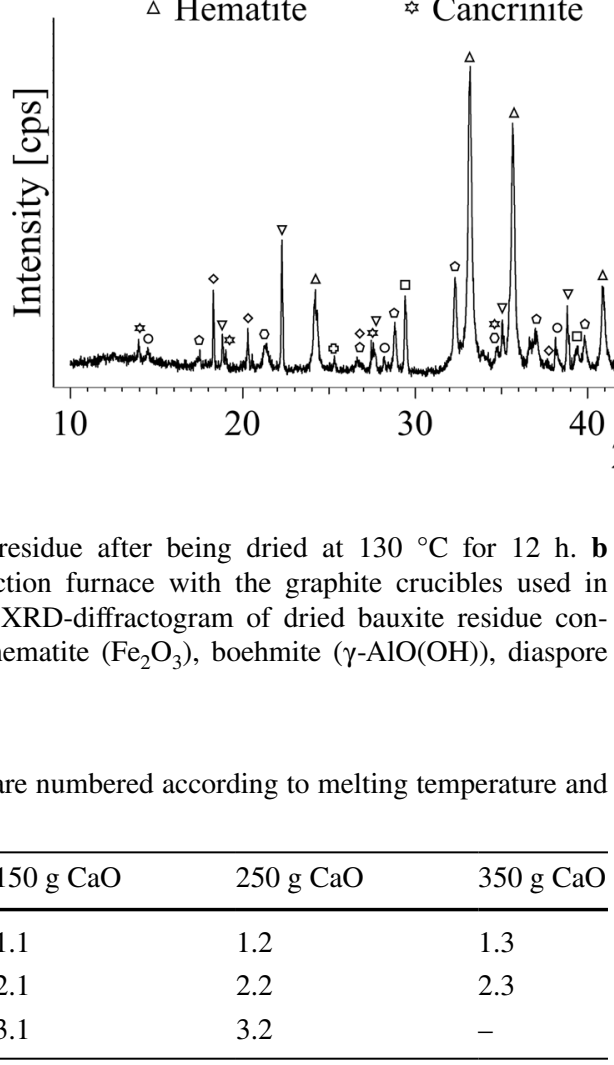

\section{Thermochemical Calculations}

The liquid slags are calculated to consist primarily of $\mathrm{Al}_{2} \mathrm{O}_{3}, \mathrm{CaO}, \mathrm{SiO}_{2}$ and $\mathrm{TiO}_{2}$. Note that the FToxid database contains limited data concerning liquid slags in the presence of $\mathrm{TiO}_{2}$ and care must be taken. The total amount of $\mathrm{TiO}_{2}$ in the liquid slag is calculated to below $5 \mathrm{wt} \%$ and the slags are extrapolated onto the $\mathrm{Al}_{2} \mathrm{O}_{3}-\mathrm{CaO}-\mathrm{SiO}_{2}$ ternary phase diagram in Fig. 2a. The distribution of $\mathrm{Ti}$ at smelting temperatures in (b) does, however, suggest that the Tirich perovskite phase is not completely molten at $1550{ }^{\circ} \mathrm{C}$.
$(\alpha-\mathrm{AlO}(\mathrm{OH}))$, gibbsite $\left(\gamma-\mathrm{Al}(\mathrm{OH})_{3}\right)$, katoite $\left(\mathrm{Ca}_{3} \mathrm{Al}_{2}\left(\mathrm{SiO}_{4}\right)(\mathrm{OH})_{8}\right)$, calcite $\left(\mathrm{Ca}\left(\mathrm{CO}_{3}\right)\right)$, cancrinite $\left(\mathrm{Na}_{6.6} \mathrm{Ca}_{0.9} \mathrm{Si}_{6.5} \mathrm{Al}_{5.5} \mathrm{O}_{24}\left(\mathrm{CO}_{3}\right)_{1.44} \cdot 2 \mathrm{H}_{2} \mathrm{O}\right)$, sodium aluminum silicate $\left(\mathrm{Na}_{1.15} \mathrm{Al}_{1.15} \mathrm{Si}_{0.85} \mathrm{O}_{4}\right)$ and anatase $\left(\mathrm{TiO}_{2}\right)$

Subsequent Scheil-Gulliver cooling calculations on the liquid slags results in the phase distributions summarized in Fig. 2c. Commonly formed phases are C12A, C3A $\alpha-\mathrm{C} 2 \mathrm{~S}$ and $\mathrm{CaTi}$. The latter is a collective term for various calcium titanates formed, including $\mathrm{CaTi}_{(\mathrm{ss})}\left(\mathrm{a} \mathrm{Ca}_{3} \mathrm{Ti}_{2} \mathrm{O}_{7(\mathrm{~s})}\right.$ $\mathrm{Ca}_{3} \mathrm{Ti}_{2} \mathrm{O}_{6(\mathrm{~s})}$ solid solution), $\mathrm{Ca}_{3} \mathrm{Ti}_{2} \mathrm{O}_{7(\mathrm{ss})}$ and perovskite ${ }_{(\mathrm{ss})}$ $\left(\mathrm{Ca}_{2} \mathrm{Ti}_{2} \mathrm{O}_{6(\mathrm{~s})}-\mathrm{Ca}_{2} \mathrm{Ti}_{2} \mathrm{O}_{5(\mathrm{~s})}\right.$ solid solution). Samples at low $\mathrm{CaO}$-additions also form a melilite solution, which contains $\mathrm{C} 2 \mathrm{AS}$ as an endmember, while samples at high $\mathrm{CaO}$-additions also form CA.

\section{Smelting}

Smelting produced pig-iron and slags and intact samples appear as in Fig. 3a. The graphite crucible cracked for several experiments (b) and repeating some of these samples resulted in similar outcomes. An overview of cracked samples is listed in Table 3, and the entries refer to Fig. 3c-f for the observed colors of the slags. The crucible for sample 3.1 did not crack but comprised of a combination of 
Fig. 2 a Calculated liquid slag compositions extrapolated onto the $\mathrm{Al}_{2} \mathrm{O}_{3}-\mathrm{CaO}-\mathrm{SiO}_{2}$ ternary phase-diagram. b Distribution of Ti between liquid metal (Liquid), liquid slag (Slag), carbides (FCC), perovskite (Pero) and calcium titanate (CaTi) at melting temperatures. c Calculated phase distribution of samples after performing Scheil-Gulliver cooling calculations on the previously calculated liquid slags (a)
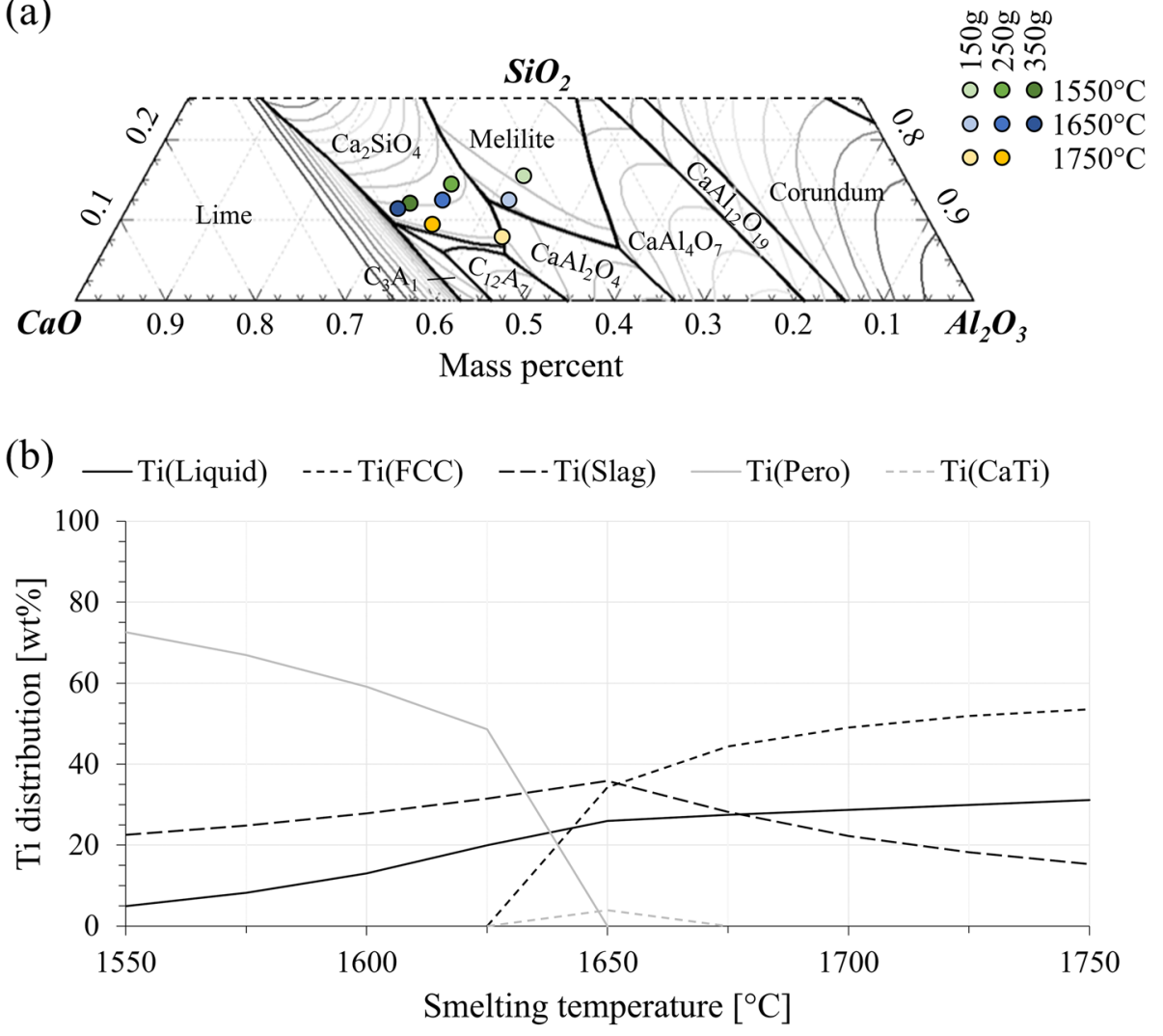

(c)

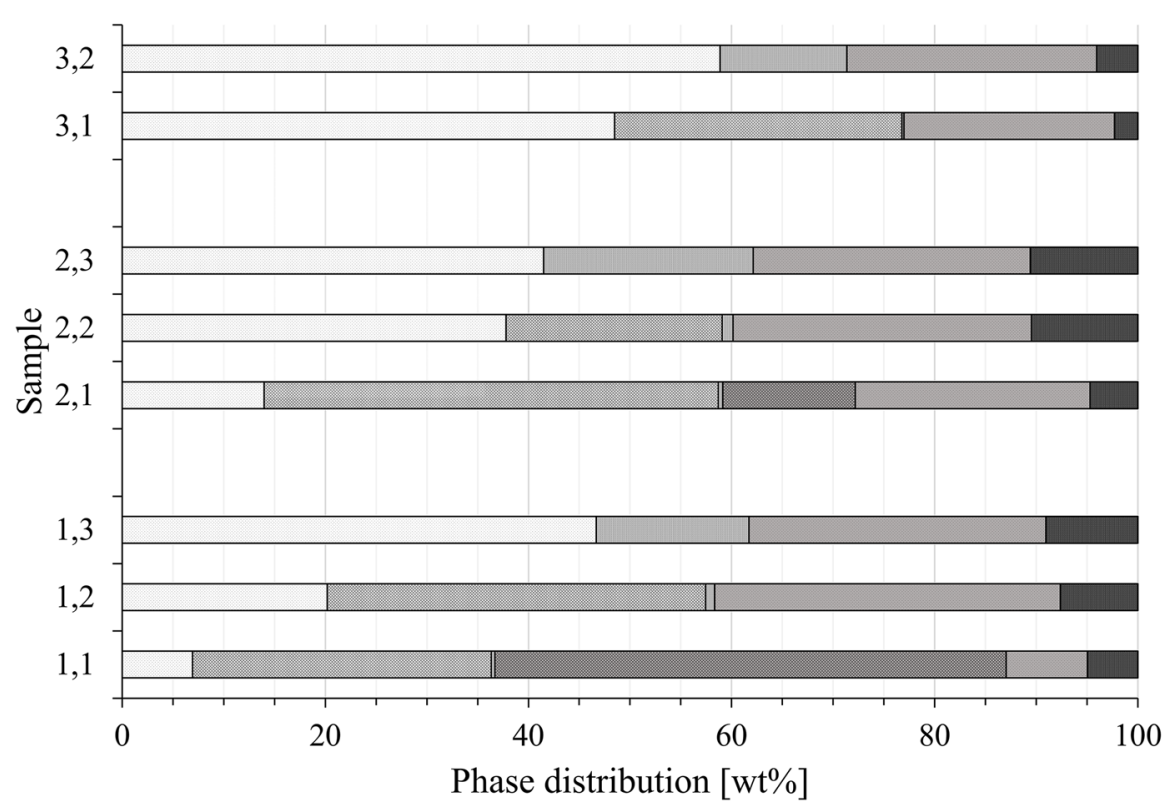

solid and powdered slag, and the sample is therefore noted as semi-intact. For cracked and semi-intact samples, the pig-iron slab was easily separable from the powdered slag, whereas the latter was sieved to below $125 \mu \mathrm{m}$ with little effort.

\section{Pig-Iron Characteristics}

With a concentration over $95 \%, \mathrm{Fe}$ is found to be the primary component of all samples (Table 4). The concentration of Si remains low for all samples at $1550^{\circ} \mathrm{C}$ and $1650{ }^{\circ} \mathrm{C}$, but 
Fig. 3 a Intact samples consist of pig-iron on the bottom and slag on top. b Samples 1.1, 1.2 and 2.2 cracked during cooling and are already pulverized after solidification. Cracked slags display a white base color $\mathbf{c}$ with or $\mathbf{d}$ without a green tint. Intact slags from samples at $1550 / 1650{ }^{\circ} \mathrm{C}$ display a e grey color, while slags from samples at $1750{ }^{\circ} \mathrm{C}$ display $\mathbf{f}$ a dark green color
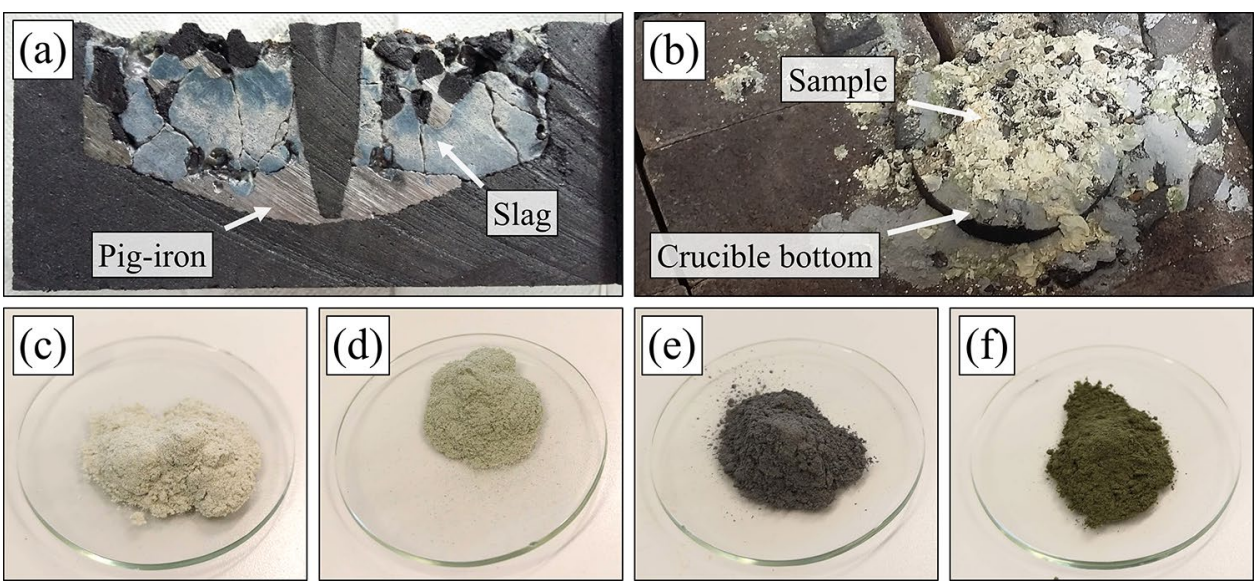

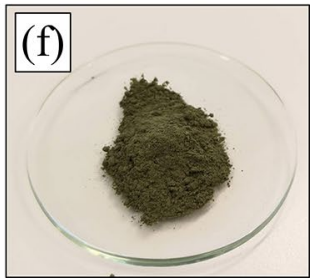

Table 3 Overview over which samples resulted in intact or cracked crucibles. The color of the respective slags are marked and refers to Fig. 3c-f

\begin{tabular}{llll}
\hline & $150 \mathrm{~g} \mathrm{CaO}$ & $250 \mathrm{~g} \mathrm{CaO}$ & $350 \mathrm{~g} \mathrm{CaO}^{\circ}$ \\
\hline $1550{ }^{\circ} \mathrm{C}$ & Cracked $^{\mathrm{b}}$ & Cracked $^{\mathrm{a}}$ & Intact $^{\mathrm{c}}$ \\
$1650{ }^{\circ} \mathrm{C}$ & Intact $^{\mathrm{c}}$ & Cracked $^{\mathrm{a}}$ & Intact $^{\mathrm{c}}$ \\
$1750{ }^{\circ} \mathrm{C}$ & Semi-intact $^{\mathrm{d}}$ & Intact $^{\mathrm{d}}$ & - \\
\hline
\end{tabular}

${ }^{\mathrm{a}}$ White

${ }^{\mathrm{b}}$ White w/green tint

${ }^{\mathrm{c}}$ Grey

${ }^{\mathrm{d}}$ Green

increases to $2.5-3.5 \%$ at $1750{ }^{\circ} \mathrm{C}$. Small levels of dissolved chromium $(\mathrm{Cr})$ and nickel $(\mathrm{Ni})$ are also found. While not found to dissolve significantly in the metal, Ti is frequently found as precipitated titanium carbide (TiC) particles along graphite flakes, which are found in abundance throughout the metal phase (Fig. 4).

\section{Slag Characteristics and Leaching}

The chemical composition of the various slags prior to and after leaching is summarized in Tables 5 and 6, respectively. Both fractions of sample 3.1 (powder and solid) display similar chemical compositions and are represented by the same column. The slags are, as predicted, generally found to be rich in $\mathrm{CaO}$ and $\mathrm{Al}_{2} \mathrm{O}_{3}$, with lesser concentrations of $\mathrm{SiO}_{2}$,
$\mathrm{TiO}_{2}$ and, in some cases, metallic Fe. Elevated Fe concentrations are primarily found in slags from intact samples (Table 3) that was crushed before further treatment and/or characterization.

From this point, the slags are divided into three groups based on similarities found in their respective XRD-diffractograms presented in Fig. 5. Note that the figure includes diffractograms of residual slag both prior to and after leaching. Samples 1.3 and 2.3 are grouped together in Group I, which display particularly strong signals for $\mathrm{C} 3 \mathrm{~A}$ together with signals for $\mathrm{C} 12 \mathrm{~A}$, larnite $(\beta-\mathrm{C} 2 \mathrm{~S})$ and $\mathrm{CaTiO}_{3}$ prior to leaching. Similar phases are also seen after leaching, i.e. $\mathrm{C} 3 \mathrm{~A}, \mathrm{C} 12 \mathrm{~A}, \beta-\mathrm{C} 2 \mathrm{~S}$ and $\mathrm{CaTiO}_{3}$, in addition to calcite and vaterite; both being polymorphs of $\mathrm{CaCO}_{3}$. Samples 1.1 and 2.1 are grouped together in Group II, displaying a particularly strong signal for C2AS together with signals for $\mathrm{C} 12 \mathrm{~A}$,

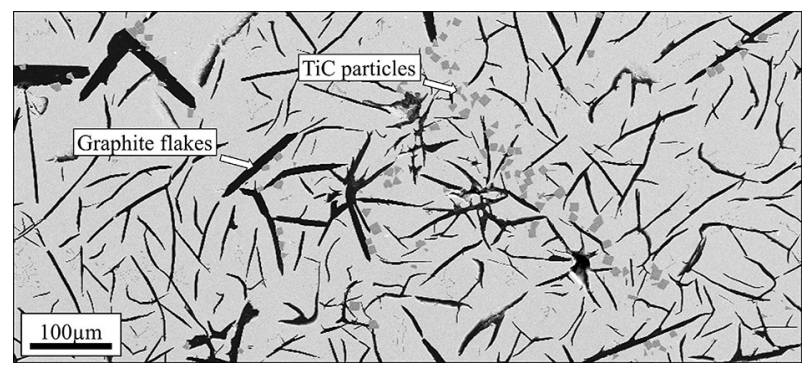

Fig. 4 Micrograph revealing the large number of graphite flakes and TiC-particles commonly found in all metal samples
Table 4 Summary of the chemical composition of the pig-iron for all samples, as measured by EPMA

\begin{tabular}{lrrrrrrrr}
\hline$\#$ & \multicolumn{1}{c}{1.1} & \multicolumn{1}{c}{1.2} & \multicolumn{1}{c}{1.3} & \multicolumn{1}{c}{2.1} & \multicolumn{1}{c}{2.2} & \multicolumn{1}{c}{2.3} & 3.1 & 3.2 \\
\hline $\mathrm{Si}$ & 0.26 & 0.28 & 0.09 & 0.09 & 0.01 & 0.00 & 3.36 & 2.69 \\
$\mathrm{Ti}$ & 0.05 & 0.08 & 0.01 & 0.02 & 0.02 & 0.01 & 0.01 & 0.03 \\
$\mathrm{Cr}$ & 0.19 & 0.37 & 0.39 & 0.17 & 0.18 & 0.13 & 0.50 & 0.68 \\
$\mathrm{Fe}$ & 99.10 & 98.77 & 99.12 & 99.36 & 99.44 & 99.46 & 95.43 & 96.13 \\
$\mathrm{Ni}$ & 0.32 & 0.24 & 0.22 & 0.29 & 0.27 & 0.34 & 0.26 & 0.13 \\
\hline
\end{tabular}


Table 5 The chemical composition of the slags prior to leaching in $\mathrm{wt} \%$, as measured by XRF

\begin{tabular}{lrrrrrrrr}
\hline$\#$ & \multicolumn{1}{c}{1.1} & \multicolumn{1}{c}{1.2} & \multicolumn{1}{c}{1.3} & \multicolumn{1}{c}{2.1} & \multicolumn{1}{c}{2.2} & 2.3 & 3.1 & 3.2 \\
\hline $\mathrm{Na}_{2} \mathrm{O}$ & 0.2 & 0.1 & 0.0 & 0.5 & 0.1 & 0.1 & 0.2 & 0.0 \\
$\mathrm{MgO}$ & 0.5 & 0.5 & 0.5 & 0.6 & 0.5 & 0.5 & 0.3 & 0.5 \\
$\mathrm{Al}_{2} \mathrm{O}_{3}$ & 23.7 & 19.9 & 18.2 & 24.3 & 21.0 & 19.5 & 27.1 & 26.4 \\
$\mathrm{SiO}_{2}$ & 14.4 & 12.6 & 8.4 & 11.9 & 11.1 & 7.5 & 10.3 & 8.9 \\
$\mathrm{CaO}$ & 53.9 & 60.1 & 61.3 & 46.8 & 56.1 & 58.9 & 58.9 & 53.8 \\
$\mathrm{SO}_{3}$ & 0.6 & 0.5 & 0.5 & 0.6 & 0.5 & 0.4 & 0.7 & 0.6 \\
$\mathrm{TiO}_{2}$ & 5.5 & 5.4 & 7.2 & 11.3 & 9.8 & 8.5 & 1.3 & 5.5 \\
$\mathrm{Fe}$ & 0.3 & 0.4 & 3.2 & 3.1 & 0.2 & 4.0 & 0.5 & 4.0 \\
\hline
\end{tabular}

Table 6 The chemical composition of the slags after leaching, as measured by XRF in weight percent (wt\%)

\begin{tabular}{lrrrrrrrr}
\hline$\#$ & \multicolumn{1}{c}{1.1} & \multicolumn{1}{c}{1.2} & \multicolumn{1}{c}{1.3} & \multicolumn{1}{c}{2.1} & \multicolumn{1}{c}{2.2} & 2.3 & 3.1 & 3.2 \\
\hline $\mathrm{CO}_{2}$ & 10.5 & 18.7 & 27.4 & 8.4 & 19.0 & 20.6 & 27.9 & 26.9 \\
$\mathrm{Na}_{2} \mathrm{O}$ & 0.4 & 0.7 & 0.6 & 0.7 & 0.7 & 0.5 & 1.1 & 0.8 \\
$\mathrm{MgO}$ & 0.7 & 0.7 & 0.5 & 0.7 & 0.7 & 0.6 & 0.5 & 0.5 \\
$\mathrm{Al}_{2} \mathrm{O}_{3}$ & 25.3 & 14.1 & 12.5 & 25.6 & 7.6 & 12.8 & 8.6 & 10.9 \\
$\mathrm{SiO}_{2}$ & 15.7 & 12.2 & 8.6 & 14.3 & 12.5 & 10.1 & 12.5 & 10.4 \\
$\mathrm{CaO}$ & 43.2 & 49.4 & 44.3 & 39.8 & 51.2 & 48.8 & 48.3 & 48.4 \\
$\mathrm{TiO}_{2}$ & 4.0 & 3.9 & 4.4 & 9.0 & 8.1 & 6.3 & 1.0 & 2.0 \\
$\mathrm{Fe}$ & 0.2 & 0.2 & 1.7 & 1.2 & 0.1 & 0.1 & 0.0 & 0.0 \\
\hline
\end{tabular}

calcio-olivine $(\gamma-\mathrm{C} 2 \mathrm{~S}), \beta-\mathrm{C} 2 \mathrm{~S}$ and $\mathrm{CaTiO}_{3}$ prior to leaching. These samples also display similar phases after as before leaching, i.e. $\mathrm{C} 2 \mathrm{AS}, \gamma-\mathrm{C} 2 \mathrm{~S}, \beta-\mathrm{C} 2 \mathrm{~S}$ and $\mathrm{CaTiO}_{3}$, in addition to both polymorphs of $\mathrm{CaCO}_{3}$. However, the $\mathrm{C} 12 \mathrm{~A}$ signal has disappeared for both samples. Finally, samples 1.2, 2.2, 3.1 and 3.2 are grouped together in Group III, which generally display a particularly strong signal for $\mathrm{C} 12 \mathrm{~A}$ together with signals for $\gamma-\mathrm{C} 2 \mathrm{~S}, \beta-\mathrm{C} 2 \mathrm{~S}$ and $\mathrm{CaTiO}_{3}$ prior to leaching. Sample 3.2 deviates from this trend by displaying an additional signal for $\mathrm{C} 3 \mathrm{~A}$, and for sample 3.1 in that it lacks the signal for $\mathrm{CaTiO}_{3}$. After leaching, the samples in Group III display a strong calcite signal together with $\gamma-\mathrm{C} 2 \mathrm{~S}, \beta-\mathrm{C} 2 \mathrm{~S}$, $\mathrm{CaTiO}_{3}$ and vaterite. Sample 3.1 still deviates from this trend by lacking the signal for $\mathrm{CaTiO}_{3}$, and sample 3.2 for still displaying a C3A signal. The $\mathrm{C} 12 \mathrm{~A}$ signal is also much less pronounced than prior to leaching.

The recovery of $\mathrm{Al}$ and $\mathrm{Si}$ to the PLS is summarized for all slags in Fig. 6, and, with values of 5-22\%, Group I samples display the lowest recoveries. Equally low recoveries of 14-25\% can also be observed for Group II samples, while the recoveries are generally found to be larger for Group III samples than for the other groups. Sample 1.2 displays the lowest value of Group III samples, while sample 3.2 displays an average value of $40 \%$, and sample 2.2 and 3.1 display the highest recoveries of $50-60 \%$. The concentration of $\mathrm{Si}$ in the PLS remains low for all samples.
The distribution of Al has been calculated by correlating semi-quantitative XRD phase identification with measured XRF- and ICP-MS data in Fig. 7. However, due to the inherent limitations of this method, these results are considered to be semi-quantitative. $\mathrm{Al}$ is primarily found as C3A (72-87\%) and a lesser fraction of C12A (12-28\%) in Group I, primarily C2AS (66-78\%) and a lesser fraction of C12A (22-33\%) in Group II, and primarily in the form of C12A (100\%) in Group III. Sample 3.2 deviates from the general trend of Group III by distributing aluminum between C12A (70\%) and a lesser C3A fraction (30\%).

Residual slag particles after leaching have been investigated by EPMA for samples 1.2, 2.2 and 3.1, and backscatter micrographs of particles are shown in Fig. 8a and b. Supplementary elemental maps are shown in (iii) and chemical compositions of marked phases (A-D) in Table 7. Particles marked with A holds a composition that resembles that of $\mathrm{C} 2 \mathrm{~S}$. Remaining $\mathrm{C} 12 \mathrm{~A}$ particles, e.g. as B in (i), are often found to be surrounded by a darker peripheral layer of $\mathrm{CaCO}_{3}$ after leaching (C). Individual particles consisting of $\mathrm{CaO}, \mathrm{TiO}_{2}$ and $\mathrm{Al}_{2} \mathrm{O}_{3}$ (D), which is believed to be Al-rich $\mathrm{CaTiO}_{3}$, can also be frequently found in the samples. The degree of overlap of the Ti-signal with the Al-signal in the EPMA maps in (iii) suggests that there is a significant incorporation of Al in the $\mathrm{CaTiO}_{3}$ structure. 
Fig. 5 XRD diffractograms of slags before and after leaching. The slags are grouped together into three groups based on similar diffractograms
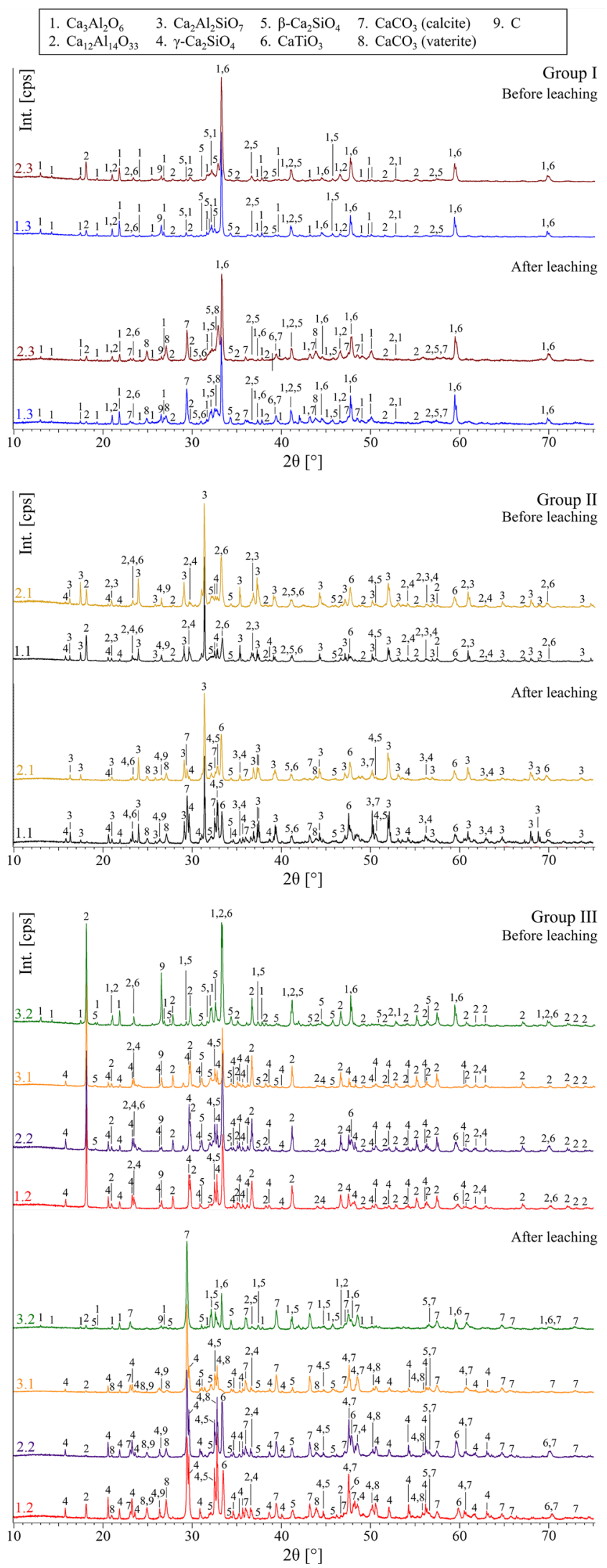

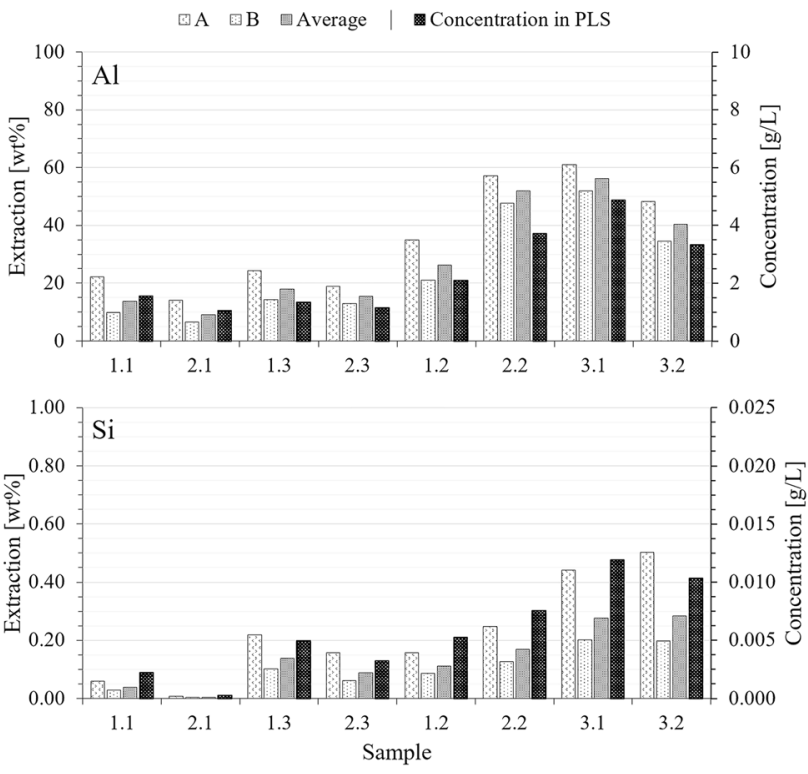

Fig. 6 The recovery of $\mathrm{Al}$ and $\mathrm{Si}$ has been calculated by correlating the concentrations measured in the PLS by ICP-MS with that measured in the slags both prior to (A; Table 5) and after (B; Table 6) leaching. The concentration of $\mathrm{Al}$ and $\mathrm{Si}$ in the PLS is included on a secondary y-axis

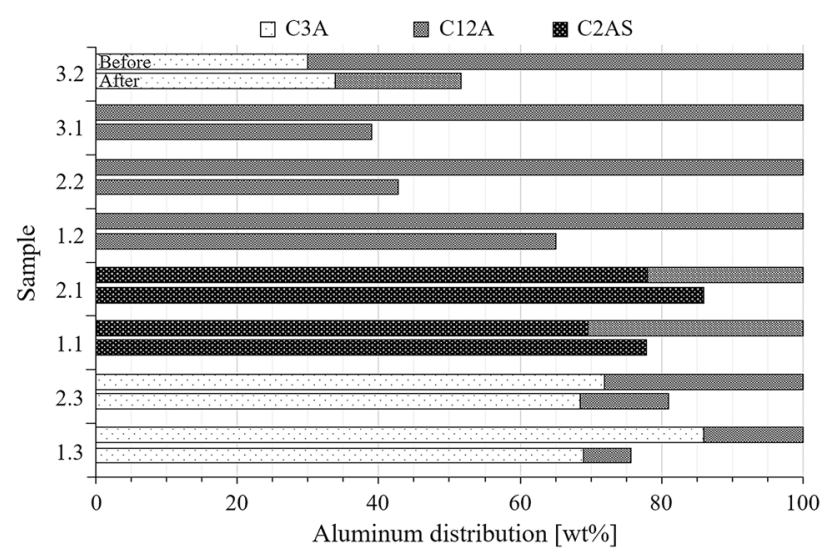

Fig. 7 Semi-quantitative (XRD) distribution of aluminum in each sample before and after leaching. The data has been correlated with XRF measurements and normalized to the amount of aluminum input before leaching. The difference between the two bars in each pair corresponds to the amount of recovered aluminum measured by ICP-MS (Fig. 6)

\section{Discussion}

\section{Pig-Iron Characteristics}

Most of the iron oxide present in the bauxite residue has been reduced to pig-iron in the bottom of the crucibles
(Fig. 3a), which may have a wide range of use, including wrought iron, steels, cast irons and other ferroalloys. Restrictions in minor elements will, however, limit the usability of the iron phase, as they affect the mechanical properties of the metal in various ways. The abundance of graphite flakes found in Fig. 4 is a result of high carbon saturation. $\mathrm{Cr}, \mathrm{Ni}$ and $\mathrm{Si}$ found in the pig-iron (Table 4) are all well-known alloying elements in steel- and ironmaking $[24,25]$. Incorporation of silicon in the metal phase does, however, require high temperatures, and significant recovery of Si to the pig-iron phase is only observed in samples produced at $1750{ }^{\circ} \mathrm{C}$ (Table 4). Si units are sought after and optimizing the process for higher recoveries will be relevant. However, higher temperatures and silicon content will also lead to increased Ti-recovery, and even though low levels of Ti has found uses in steel- and ironmaking [25] it is generally not added intentionally. One should therefore find ways to limit its presence in the pig-iron phase. Although the alloyed elements may have their individual uses, the fact that they are present together may not be as propitious, and one may have to find solutions for limiting their presence in order to develop products that may be able to accommodate pig-iron produced from bauxite residue.

\section{Slag Characteristics and Leaching}

There is a general agreement between calculated (Fig. 2c) and experimental (Fig. 5) results in that the C12A phase can be formed if the addition of $\mathrm{CaO}$ is tuned appropriately. Adding too little $\mathrm{CaO}$ will reduce the amount of $\mathrm{C} 12 \mathrm{~A}$, and Group II samples display the lowest aluminum recoveries of 10-20\% (Fig. 6). Calculations suggest that CA and C2AS form at lower $\mathrm{CaO}$ additions but, according to Fig. 5, CA cannot be identified in any of the diffractograms. The low recoveries in Group II samples can be related to the small fraction of the highly leachable $\mathrm{C} 12 \mathrm{~A}$ phase found alongside the insoluble C2AS phase (Fig. 7). On the assumption that C2AS does not react with the sodium carbonate solution, there is a small discrepancy in the content of C2AS before and after leaching in the figure, hence manifesting the inherent uncertainty in the semi-quantitative XRD phase identification method and XRF measurements. However, with appropriate care, the data has been considered to be accurate enough to describe general trends in the samples.

The $\mathrm{C} 12 \mathrm{~A}$ phase is found to be the predominant Al-bearing phase in Group III and, with the exception of sample 1.2, they display the highest Al-recoveries of all sample (Fig. 6). The high recoveries can be related to $\mathrm{Al}$ being contained within the highly leachable C12A phase (Fig. 7). However, residual $\mathrm{C} 12 \mathrm{~A}$ in the samples after leaching indicates incomplete leaching. The surface of the calcium-aluminate particles gets covered in a passivating $\mathrm{CaCO}_{3}$ layer during 


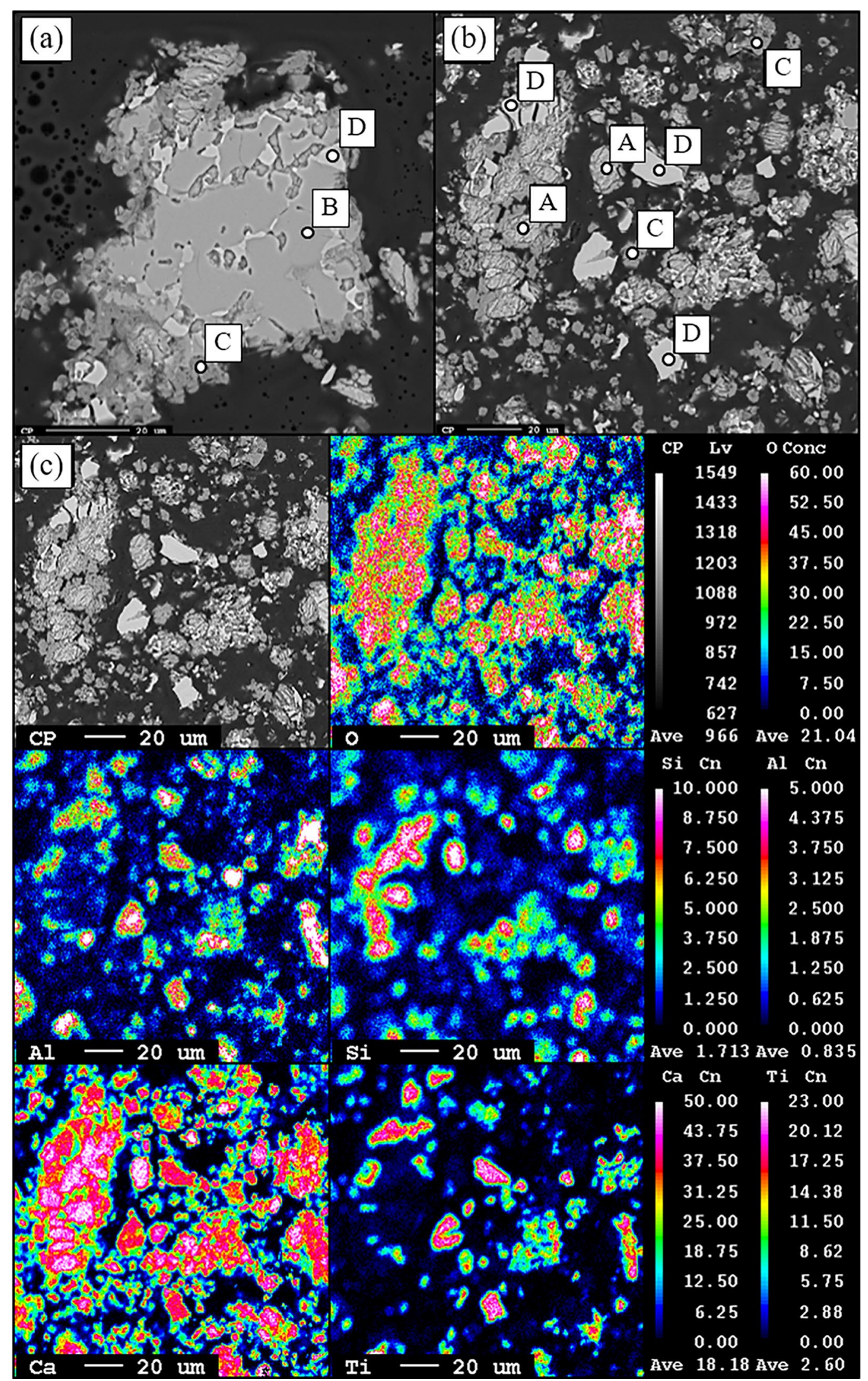

Fig. 8 Micrograph and EPMA maps of oxygen, aluminum, silicon, calcium and titanium for sample 2.2 after leaching. Marked particles are quantified in more detailed in Table 7 
Table 7 Averaged EPMA point measurements of phases in samples 1.2, 2.2 and 3.1 after leaching in $w t \%$

\begin{tabular}{lrlrrrr}
\hline$\#$ & \multicolumn{1}{l}{$\mathrm{CO}_{2}$} & \multicolumn{1}{l}{$\mathrm{MgO}$} & \multicolumn{1}{c}{$\mathrm{Al}_{2} \mathrm{O}_{3}$} & \multicolumn{1}{c}{$\mathrm{SiO}_{2}$} & \multicolumn{1}{c}{$\mathrm{CaO}$} & \multicolumn{1}{c}{$\mathrm{TiO}_{2}$} \\
\hline $\mathrm{A}$ & $6.84 \pm 3.78$ & $0.10 \pm 0.04$ & $0.80 \pm 0.37$ & $30.14 \pm 0.31$ & $60.69 \pm 3.74$ & $1.43 \pm 0.02$ \\
$\mathrm{~B}$ & $0.00 \pm 0.00$ & $0.56 \pm 0.37$ & $52.52 \pm 1.82$ & $1.32 \pm 2.70$ & $45.34 \pm 2.65$ & $0.21 \pm 0.29$ \\
$\mathrm{C}$ & $40.31 \pm 6.50$ & $0.31 \pm 0.25$ & $2.72 \pm 3.67$ & $1.13 \pm 2.00$ & $55.32 \pm 5.98$ & $0.18 \pm 0.32$ \\
$\mathrm{D}$ & $1.19 \pm 1.79$ & $0.21 \pm 0.06$ & $15.47 \pm 3.42$ & $1.70 \pm 0.44$ & $44.07 \pm 0.95$ & $37.19 \pm 1.80$ \\
\hline
\end{tabular}

Associated phases are marked in Fig. 8

\begin{tabular}{|c|c|c|c|c|c|c|c|c|}
\hline [wt\%] & Gr. 1 & & Gr. 2 & & Gr. 3 & & & \\
\hline Sample & 1.3 & 2.3 & 1.1 & 2.1 & 1.2 & 2.2 & 3.1 & 3.2 \\
\hline$\gamma$-to- $\beta$ ratio & 0.1 & 0.3 & 2.2 & 0.6 & 5.0 & 4.2 & 1.2 & 0.2 \\
\hline
\end{tabular}

Table 8 Ratio of $\gamma-\mathrm{Ca}_{2} \mathrm{SiO}_{4}$ versus $\beta-\mathrm{Ca}_{2} \mathrm{SiO}_{4}$ in the slags, as calculated from semiquantitative XRD phase analysis are clearly dominated by $\mathrm{C} 3 \mathrm{~A}$. The recovery of $\mathrm{Al}$ is also considerably lower, as only a small fraction of the $\mathrm{Al}$ is contained within the $\mathrm{C} 12 \mathrm{~A}$ phase. For sample 1.3 , the recovery of $\mathrm{Al}$ surpasses the amount which can be related to $\mathrm{C} 12 \mathrm{~A}$ (Fig. 7). However, while C3A is known to be a leachable phase, it cannot be said with certainty if this can be related to combined leaching of $\mathrm{C} 12$ and $\mathrm{C} 3 \mathrm{~A}$ or the semi-quantitative nature of the data that was used to calculate the distribution in Fig. 7. Samples 2.3 and 3.2, on the other hand, suggest insignificant leaching of the $\mathrm{C} 3 \mathrm{~A}$ phase in current experiments, and different leaching parameters may be required to accommodate for leaching of this phase [9]. Thermodynamics suggests that the $\mathrm{C} 12 \mathrm{~A}$ phase can be promoted by increasing the smelting temperature of the samples with lowest $\mathrm{CaO}$ additions (150 g; Fig. 2c). The higher temperature increases the preference of $\mathrm{Si}$ for entering the pig-iron and escaping the melt as $\mathrm{SiO}_{(\mathrm{g})}$, altering the slag composition to one that is favorable in terms of $\mathrm{C} 12 \mathrm{~A}$ and preventive in terms of C2AS formation.

Phase identification (Fig. 5) clearly shows that $\gamma$-and $\beta-\mathrm{C} 2 \mathrm{~S}$ are the primary silicate phases in the slags. The high-temperature $\alpha$-polymorph transforms into its $\beta$ - and $\gamma$-counterparts when reaching temperatures of 675 and $490{ }^{\circ} \mathrm{C}$, respectively. The $\beta$ - to $\gamma$ - transformation is associated with a particularly large volume expansion of $12 \%$ that may be utilized for achieving slags that disintegrate upon cooling [20]. Several slags cracked during cooling, leaving a powdery slag (Table 3 ), and semi-quantitative phase identification has been used to calculate the $\gamma$-to- $\beta$ ratio of all samples in Table 8 , and there is a clear correlation between the cracking behavior and $\gamma$-to- $\beta$ ratios. Samples with ratios below unity remained intact, while samples with ratios much higher than unity cracked. Sample 3.1 , with a ratio of 1.2 , was found to be semi-intact. It is therefore reasonable to assume that the observed cracking can be related to formation of $\gamma-\mathrm{C} 2 \mathrm{~S}$. However, the reason behind the varying $\gamma$-to- $\beta$ ratios is still unclear. $\beta$-C2S is metastable at room-temperature and will preferably 
transform into $\gamma$-C2S if stabilizing conditions are not met. This transformation is unwanted e.g. in production of cement and steels, and a significant effort is put on developing methods for stabilizing $\beta$-C2S. Disintegration can be prevented by physical and chemical stabilization techniques, and methods covered in literature include (i) rapid cooling at rates higher than $5{ }^{\circ} \mathrm{C} / \mathrm{s}$, (ii) altering the slag chemistry to limit/avoid formation of $\mathrm{C} 2 \mathrm{~S}$ altogether and (iii) chemical stabilization by additives [27]. Current experiments are not compatible with (i) and (ii) in that samples are cooled by natural convection and that one does not seek to avoid formation of C2S. Samples 1.1 and 2.1 display opposite cracking behavior, despite both capturing significant amounts of $\mathrm{Si}$ in C2AS. Small concentrations of various oxides have proven to have a stabilizing effect by forming solid solutions with C2S [28]. A recent study found that the addition of up to $3 \%$ of $\mathrm{TiO}_{2}$ effectively stabilized the $\beta$-polymorph by substituting $\mathrm{Si}^{4+}$ in the $\mathrm{SiO}_{4}{ }^{2-}$ tetrahedron with $\mathrm{Ti}^{4+}$ [29]. This suggests that the content of Ti may offer some stabilization to the $\beta-\mathrm{C} 2 \mathrm{~S}$ phase in the current samples, but the results require additional analysis that may be targeted in a later study.

All in all, this work has successfully synthesized pig-iron and calcium aluminate slags with various properties. The usability of the pig-iron is assumed to be limited to production of certain cast irons that may be able to handle the inhomogeneous nature of the bauxite residue and its impurities. Recovery of Al correlate well with the occurrence of the highly leachable $\mathrm{C} 12 \mathrm{~A}$ phase. The study shows no clear evidence for $\mathrm{Al}$ recovery from the $\mathrm{C} 3 \mathrm{~A}$ phase, and one should not rule out the possibility of higher recoveries by further optimization of the leaching process. Too low $\mathrm{CaO}$ additions may capture $\mathrm{Al}$ and $\mathrm{Si}$ in the undesirable C2AS phase, which will reduce the leachability of the slags and potentially their capability of disintegrating. Disintegration took place for samples displaying high $\gamma$-to- $\beta \mathrm{C} 2 \mathrm{~S}$ ratio, although the reasons for variable transformation from $\beta$ - to $\gamma$-C2S is still unclear. Disintegration will reduce the need for post-processing, but the recovery will still be limited by the formation of an inhibiting layer of $\mathrm{CaCO}_{3}$ on the reaction surface of the calcium-aluminate particles during leaching. The force exerted by the expanding slags was large enough to crack several crucibles, which is something that needs to be handled. Finally, one should consider if it is propitious to recover $\mathrm{Ti}$ and $\mathrm{Si}$ to the pig-iron. While exceptions do exist, Ti is generally unwanted in pig-iron, due to the formation of hard carbides and nitrides. On the other hand, numerous possible implications involving the occurrence of $\mathrm{Ti}$ in the slag have also been discussed. First and foremost, observations suggest that $\mathrm{Al}$ can be immobilized in the $\mathrm{CaTiO}_{3(\mathrm{~s})}$ structure. Furthermore, literature suggests that Ti may stabilize the $\beta-\mathrm{C} 2 \mathrm{~S}$ phase and thereby prevent slag disintegration. Increased concentration of $\mathrm{Si}$ in the pig-iron will increase its market value but will also require higher costs. It may therefore be more feasible to retain $\mathrm{Si}$ in the slag, where it can be recycled together with $\mathrm{CaCO}_{3}$ e.g. by the construction industry.

\section{Conclusions}

Pig-iron and calcium aluminate slags have been successfully synthesized from bauxite residue at temperatures of $1550-1750{ }^{\circ} \mathrm{C}$. Fe recovers primarily to the pig-iron, and $\mathrm{CaO}$ are added to optimize the composition of the slag to one that favors formation of the highly leachable mayenite phase. While there is a clear correlation between the amount of $\mathrm{Al}$ recovered and the occurrence of the mayenite phase, it is still limited to a maximum of $50-60 \%$. The formation of an inhibiting layer of $\mathrm{CaCO}_{3}$ on the surface of the calcium aluminate particles and immobilization of $\mathrm{Al}$ in $\mathrm{CaTiO}_{3}$ particles are suggested to play important roles in the total recovery of $\mathrm{Al}$. Samples with low $\mathrm{CaO}$ additions are vulnerable to formation of the undesirable gehlenite phase, which effectively immobilizes $\mathrm{Al}$ and reduces the recovery considerably. Slags with high $\gamma$-to- $\beta$ C2S ratios are also found to disintegrate, which can be advantageous for post-processing of slags.

Acknowledgements This work has been funded by the European Union's Horizon 2020 program ( $\left.n^{\circ} 776469\right)$, and the authors gratefully acknowledge the financial support from the RemovAl project.

Funding Open access funding provided by NTNU Norwegian University of Science and Technology (incl St. Olavs Hospital - Trondheim University Hospital).

\section{Declarations}

Conflict of interest The authors declare that they have no conflict of interest.

Open Access This article is licensed under a Creative Commons Attribution 4.0 International License, which permits use, sharing, adaptation, distribution and reproduction in any medium or format, as long as you give appropriate credit to the original author(s) and the source, provide a link to the Creative Commons licence, and indicate if changes were made. The images or other third party material in this article are included in the article's Creative Commons licence, unless indicated otherwise in a credit line to the material. If material is not included in the article's Creative Commons licence and your intended use is not permitted by statutory regulation or exceeds the permitted use, you will need to obtain permission directly from the copyright holder. To view a copy of this licence, visit http://creativecommons.org/licenses/by/4.0/.

\section{References}

1. Balomenos E (2018) Could 'red mud' be the answer to some of Europe's critical-metal supply concerns? EU MSCA-ETN 
REDMUD Policy Brief, no. 636876, EU MSCA-ETN REDMUD Policy Brief, pp 1-9

2. Tam P, Xakalashe BS, Friedrich B, Panias D (2017) Carbothermic reduction of bauxite residue for iron recovery and subsequent aluminium recovery from slag leaching. In: Trav. 46, Proc. 35th Int. ICSOBA Conf., pp 603-614

3. Dentoni V, Grosso B, Massacci G (2014) Environmental sustainability of the alumina industry in Western Europe. Sustainability 6(12):9477-9493

4. Council of the European Union, European Parliament (2006) Directive 2006/21/EC of the European Parliament and of the Council of 15 March 2006 on the management of waste from extractive industries and amending Directive 2004/35/EC

5. European Commission: EU Waste Legislation (2016)

6. Miller J, Irgens A (2017) Alumina production by the Pedersen process-history and future. Essent Read Light Met 1:977-982

7. Vafeias M, Marinos D, Panias D, Safarian J, Van Der Eijk C, Solhem I, Balomenos E, Ksiazek M, Davris P (2018) From red to grey: revisiting the Pedersen process to achieve holistic bauxite ore utilisation. In: Proc. 2nd Int. Bauxite Residue Valoris. Best Pract. Conf., pp 111-117

8. Safarian J, Kolbeinsen L (2016) Sustainability in alumina production from bauxite. Sustain Ind Process Summit 5:75-82

9. Azof FI, Kolbeinsen L, Safarian J (2017) The leachability of calcium aluminate phases in slags for the extraction of alumina. In: Trav. 46, Proc. 35th Int. ICSOBA Conf., vol 42, pp 243-253

10. Azof FI, Yang Y, Panias D, Kolbeinsen L, Safarian J (2019) Leaching characteristics and mechanism of the synthetic calcium-aluminate slags for alumina recovery. Hydrometallurgy 185:273-290

11. Edmonds RN, Majumdar AJ (1988) The hydration of $12 \mathrm{CaO} .7 \mathrm{~A}_{2} \mathrm{O}_{3}$ at different temperatures. Cem Concr Res 18(3):473-478

12. Zhmoidin GI, Chatterjee AK (1984) Conditions and mechanism of interconvertibility of compounds $12 \mathrm{CaO} .7 \mathrm{Al}_{2} \mathrm{O}_{3}$ and $5 \mathrm{CaO} .3 \mathrm{Al}_{2} \mathrm{O}_{3}$. Cem Concr Res 14(3):386-396

13. Eufinger JP, Schmidt A, Lerch M, Janek J (2015) Novel anion conductors-conductivity, thermodynamic stability and hydration of anion-substituted mayenite-type cage compounds C12A7: $\mathrm{X}(\mathrm{X}=\mathrm{O}, \mathrm{OH}, \mathrm{Cl}, \mathrm{F}, \mathrm{CN}, \mathrm{S}, \mathrm{N})$. Phys Chem Chem Phys 17(10):6844-6857

14. Kim SW, Miyakawa M, Hayashi K, Sakai T, Hirano M, Hosono H (2005) Simple and efficient fabrication of room temperature stable electride: melt-solidification and glass ceramics. J Am Chem Soc 127(5):1370-1371

15. Salasin JR, Schwerzler SEA, Mukherjee R, Keffer DJ, Sickafus KE, Rawn CJ (2018) Direct formation and structural characterization of electride C12A7. Materials 12(1):84
16. Azof FI, Vafeias M, Panias D, Safarian J (2020) The leachability of a ternary $\mathrm{CaO}-\mathrm{Al}_{2} \mathrm{O}_{3}-\mathrm{SiO}_{2}$ slag produced from smelting-reduction of low-grade bauxite for alumina recovery. Hydrometallurgy 191:105184

17. Hodge H, Rowles MR, Hayes PC, Hawker W, Vaughan J (2019) Bauxite residue sinter leach process - phases formation, reaction pathways and kinetics. Miner Process Extr Metall 1-13

18. Kaußen FM, Friedrich B (2016) Methods for alkaline recovery of aluminum from bauxite residue. J Sustain Metall 2(4):353-364

19. Blake HE, Fursman OC, Fugate AD, Banning LH (1976) Adaptation of the Pedersen process to the ferruginous bauxites of the pacific northwest. U.S. Department of the Interior, Bureau of Mines, Washington

20. Chan CJ, Kriven WM, Young JF (1992) Physical stabilization of the $\beta \rightarrow \gamma$ transformation in dicalcium silicate. J Am Ceram Soc 75(6): 1621-1627

21. Bo W, Hui-lan S, Xue-zheng Z, Shi-wen B (2011) The effect of cooling rate on the leachability of calcium aluminate slags. Light Met 2011:241-244

22. Bale CW et al (2016) FactSage thermochemical software and databases, 2010-2016. Calphad Comput Coupling Phase Diagrams Thermochem 54:35-53

23. Hallstedt B (1990) Assessment of the CaO-A1203 system. J Am Ceram Soc 73(1):15-23

24. Davis JR (1996) ASM Specialty Handbook: Cast Irons. ASM International

25. Gasik M (2013) Handbook of ferroalloys: theory and technology. Butterworth-Heinemann, Waltham

26. Dunyushkina LA, Gorbunov VA, Babkina AA, Esina NO (2003) High-temperature electrical transport in Al-doped calcium and strontium titanates. Ionics 9(1-2):67-70

27. Pontikes Y, Jones PT, Geysen D, Blanpain B (2010) Options to prevent dicalcium silicate-driven disintegration of stainless steel slags. Arch Metall Mater 55(4):1167-1172

28. Gollapalli V, Tadivaka SR, Borra CR, Varanasi SS, Karamched PS, VenkataRao MB (2020) Investigation on stabilization of ladle furnace slag with different additives. J Sustain Metall 6(1):121-131

29. Maiti SC, Ghoroi C (2017) Influence of catalytic nano-additive for stabilization of $\beta$-dicalcium silicate and its hydration rate with different electrolytes. Cem Concr Res 98:111-121

Publisher's Note Springer Nature remains neutral with regard to jurisdictional claims in published maps and institutional affiliations.

\title{
Authors and Affiliations
}

\author{
K. E. Ekstroem ${ }^{1}$ (D - A. Voll Bugten ${ }^{1} \cdot$ C. van der Eijk $^{2} \cdot$ A. Lazou $^{1} \cdot$ E. Balomenos $^{3} \cdot$ G. Tranell $^{1}$ \\ K. E. Ekstroem \\ kai.e.ekstrom@ntnu.no \\ 1 Norwegian University of Science and Technology, \\ Trondheim, Norway \\ 2 SINTEF Industry, Trondheim, Norway
}

